\title{
Effect of Ball-Milling on Sinterability of Si-Ge Powders Prepared by Gas Atomization of the Corresponding Melts
}

\author{
Masatoshi OTAKE, Kenji SATO, Osamu SUGIYAMA* and Shoji KANEKO** \\ Hamamatsu Industrial Research Institute, 1-3-3, Shinmiyakoda, Hamamatsu-shi, Shizuoka 431-2103 \\ *Fuji Industrial Research Institute, 2590-1, Obuchi, Fuji-shi, Shizuoka 417-0801 \\ **Department of Materials Science and Technology, Faculty of Engineering, Shizuoka University, \\ 3-5-1, Johoku, Hamamatsu-shi, Shizuoka 432-8561
}

\author{
溶融体のガスアトマイズより作製された Si-Ge 粉体の焼結性に及ぼすボールミル効果 \\ 大竹正寿·佐藤憲治·杉山 治* ·金子正治** \\ 静岡県浜松工業技術センター, 431-2103 静岡県浜松市新都田 1-3-3 \\ *静岡県富士技術センター, 417-0801 静岡県富士市大㴊 2590-1 \\ **静岡大学工学部物質工学科, 432-8561 静岡県浜松市城北 3-5-1
}

\begin{abstract}
Each p- and n-type powder of $\mathrm{Si}_{0.8} \mathrm{Ge}_{0.2}$ for thermoelectric elements was prepared by gas atomization of the corresponding melts. Then, the relationship between the characteristics of $\mathrm{Si}-\mathrm{Ge}$ powders and their sinterability was studied. Particular emphasis was placed upon understanding the effect of ball-milling on the sinterability of the as-prepared powders. The composition of the as-prepared powder was different from the batch composition due to melting and evaporation of the dopant above $1550 \mathrm{~K}$. Ball-milling made the particle size of the as-prepared powders small, presumably together with introducing distortion to the crystal lattice. Densification of as-prepared powders was abruptly promoted above $1500 \mathrm{~K}$ by a pulse-current sintering; however, this densification temperature of the powders after ball-milling was lowered by approximately $100 \mathrm{~K}$. The grain size and elemental inhomogeneity of the dense body after sintering were also reduced by ball-milling process.

[Received April 25, 2003; Accepted July 24, 2003]
\end{abstract}

Key-words : Silicon-germanium, Ball-milling, Sinterability, Gas atomization, Thermoelectric element

\section{Introduction}

Thermoelectric element converts thermal energy to electrical energy using temperature difference in the element and is composed of joined p- and n-type thermoelectric materials. ${ }^{1)}$ The power generator using $\mathrm{Si}-\mathrm{Ge}$ thermoelectric elements for artificial satellites is one of the most successful applications. ${ }^{2)} \mathrm{Si}-\mathrm{Ge}$ thermoelectric elements were mostly made by hot pressing of powders obtained by pulverizing the corresponding ingots. ${ }^{3-6)}$ Here, the sinterability of pulverized thermoelectric material is quite significant because many physical properties on the thermoelectricity such as resistivity and thermal conductivity are firmly connected to the density of shaped bodies. Vining et al. fabricated $\mathrm{Si}-\mathrm{Ge}$ dense bodies of $2.87-3.05 \times 10^{3} \mathrm{~kg} \cdot \mathrm{m}^{-3}$ in density by hot pressing of powders with various grain sizes ranging from $\left.1-100 \mu \mathrm{m} .{ }^{7}\right)$ Beaty and coworkers obtained dense bodies of the density of more than $98 \%$ by the same sintering process from ultra-fine (5 to $10 \mathrm{~nm}$ ) Si-Ge powders. ${ }^{8), 9)}$

An atomizing technique suitable for production of homogeneous metal or metal alloy powders ${ }^{10)}{ }^{-12}$ ) has also been applied to the preparation of Si-Ge powders. A Si-Ge dense body obtained by hot pressing of atomized fine powders gave the reduction of the inhomogeneity on the Si and $\mathrm{Ge}$ distribution. ${ }^{13)}$ However, the characterization and sinterability of gas-atomized $\mathrm{Si}-\mathrm{Ge}$ powders have not been studied in detail.

Pulse-current sintering is a recently developed densification technique by delivering on-off DC pulse electric current to powders under pressing. ${ }^{14)-16)}$ Pulse current may play an important role as a trigger for sintering at many contact points between particles. It can yield a dense body of metals or ceramics in a very short period compared with other hot pressings. Noguchi obtained a shaped body of density greater than $99 \%$ for 1 min as sintering soak time from poorly sinterable $\mathrm{Si}-\mathrm{Ge}$ powders by this technique. ${ }^{17}$ )

In this study, semiconducting $\mathrm{Si}-\mathrm{Ge}$ powders were obtained by the gas atomizing of the melt, followed by the densification using a pulse-current sintering. The effect of ball-milling on the sinterability of gas-atomized Si-Ge powders was then discussed based on the powder characterization.

\subsection{Sample preparation}

\section{Experimental}

A mixed powder of $80 \mathrm{~mol} \% \mathrm{Si}$ and $20 \mathrm{~mol} \% \mathrm{Ge}$ was doped by adding $0.2 \mathrm{~mol} \% \mathrm{~B}$ and $0.3 \mathrm{~mol} \% \mathrm{P}$ for $\mathrm{p}-$ and n-type semiconductor formations, respectively. After melting with a microwave-heating furnace in vacuo, the powder was atomized from a nozzle with compressed argon. As-prepared Si-Ge powder was further pulverized by a Fritsch planetary ball-mill at $400 \mathrm{rpm}$ in argon.

A powder sample of $3 \mathrm{~g}$ was charged into a cylindrical carbon vessel with an inner diameter of $20 \mathrm{~mm}$, and then uniaxially compressed with a carbon punch at $49 \mathrm{MPa}$. The sintering was carried out to fabricate a compact for a soaking time of $180 \mathrm{~s}$ in vacuo, providing a pulse current of approximately $2000 \mathrm{~A}$ and $3 \mathrm{~V}$. The sintering temperatures of as-atomized and pulverized powder were 1473 to $1533 \mathrm{~K}$ and 1273 to $1513 \mathrm{~K}$, respectively. The carbon vessel was enclosed with a carbon thermal insulator to realize a temperature uniformity of the charged powder. The sintering temperature was measured with a $\mathrm{Pt}-(\mathrm{Pt}-13 \%$ $\mathrm{Rh}$ ) thermocouple, the top of which was inserted into the vessel wall adjacent to the sample. Sintered bodies from as-prepared and pulverized powders were named sample A and sample $\mathrm{P}$, respectively, as shown in Table 1. Also, $\mathrm{p}$ - and n-type Si-Ge were denoted with the suffixes of $\mathrm{p}$ and 
Table 1. Si-Ge Sintered Bodies

\begin{tabular}{|l|l|}
\hline $\begin{array}{l}\text { Sintered body from as-prepared } \\
\text { Si-Ge powder (p-type) }\end{array}$ & Sample Ap \\
\hline $\begin{array}{l}\text { Sintered body from as-prepared } \\
\text { Si-Ge powder (n-type) }\end{array}$ & Sample An \\
\hline $\begin{array}{l}\text { Sintered body from pulverized } \\
\text { Si-Ge powder (p-type) }\end{array}$ & Sample Pp \\
\hline $\begin{array}{l}\text { Sintered body from pulverlized } \\
\text { Si-Ge powder (n-type) }\end{array}$ & Sample Pn \\
\hline
\end{tabular}

n, respectively.

2.2 Characterization

Quantitative analyses of elements of as-prepared powders were carried out by the following methods: Gravimetric method of silicon dioxide for $\mathrm{Si}$, inductively coupled plasmaatomic emission spectrometry (ICP) for Ge and B, and molybdenum blue spectrophotometric method for $\mathrm{P}$. The size distribution of the powder was obtained by a laser diffraction method. The density of the sintered body was measured by an Archimedes method and the microstructure of the body surface was observed after etching with reagent $\left(\mathrm{HNO}_{3}+\mathrm{HF}+\mathrm{H}_{2} \mathrm{O}=5: 5: 1\right)$. The transverse rupture strength was determined by the span of $10 \mathrm{~mm}$ from the sample of $2.5 \mathrm{~mm} \times 3.0 \mathrm{~mm} \times 15 \mathrm{~mm}$ which was cut from the sintered body. The morphology of the powder and fracture surface was observed by SEM. Determination of the crystalline phase and elemental analysis of both powders and sintered bodies were carried out by XRD and EPMA, respectively. Oxygen contents of the powder and sintered body were determined by measuring carbon dioxide generated from the melted sample in a carbon crucible.

\section{Results and discussion}

3.1 Characteristics of powder

The chemical compositions of as-prepared powders obtained here were Si $79.7 \mathrm{~mol} \%$, Ge $20.1 \mathrm{~mol} \%$ and B 0.21 $\mathrm{mol} \%$ for p-type Si-Ge, and Si $79.8 \mathrm{~mol} \%$, Ge $20.0 \mathrm{~mol} \%$ and $\mathrm{P} 0.18 \mathrm{~mol} \%$ for $\mathrm{n}$-type Si-Ge. The decrease of phosphorous of the n-type powder by $40 \%$ compared with the batch composition was probably due to its volatility with high vapor pressure when melted.

As-prepared n-type powder of relatively large spherical particles was observed in Fig. 1(a). The compositional inhomogeneity of Ge was observed on the surface of the powder (Fig. 1(b)), although a solid solution should be completely formed in the whole composition. ${ }^{18)}$ It is considered that the segregation of Si- and Ge-rich phases occurred during the cooling stage after $\mathrm{Si}$ and Ge starting powders were melted to form a solid solution. This phenomenon may be attributed to the low rate of diffusion of $\mathrm{Ge}$ in the Si-rich phase;13) nevertheless, a gas-atomizing process seems to be one of the quenching methods. As-prepared p- and n-type powders were relatively large particles with mean sizes of 72 and $66 \mu \mathrm{m}$, respectively, as shown in Fig. 2. Figure 3 shows the SEM images of pulverized powders after ball-milling for 1,10 and $50 \mathrm{~h}$. All pulverized powders were composed of various figures, which were partly flocculated. The size distributions of as-prepared powders were shifted to less than $5 \mu \mathrm{m}$ of the mean size by pulverizing for $10 \mathrm{~h}$, as shown in Fig. 4 . However, two peaks of approximately 1.5 and $15 \mu \mathrm{m}$ of the distribution appeared by the ball-milling for $50 \mathrm{~h}$. The appearance of the peak of $15 \mu \mathrm{m}$ was attributed to the flocculation due to an increase in the surface energy of the

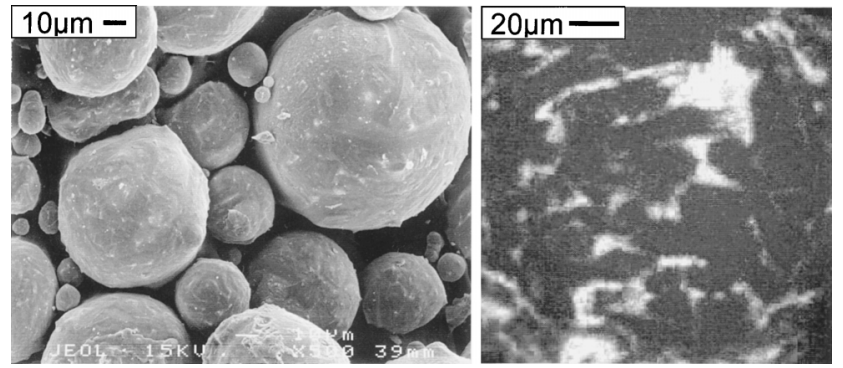

Fig. 1. (a) SEM image and (b) mapping image of Ge of as-prepared n-type $\mathrm{Si}-\mathrm{Ge}$ powder. Light gray: Ge-rich phase.

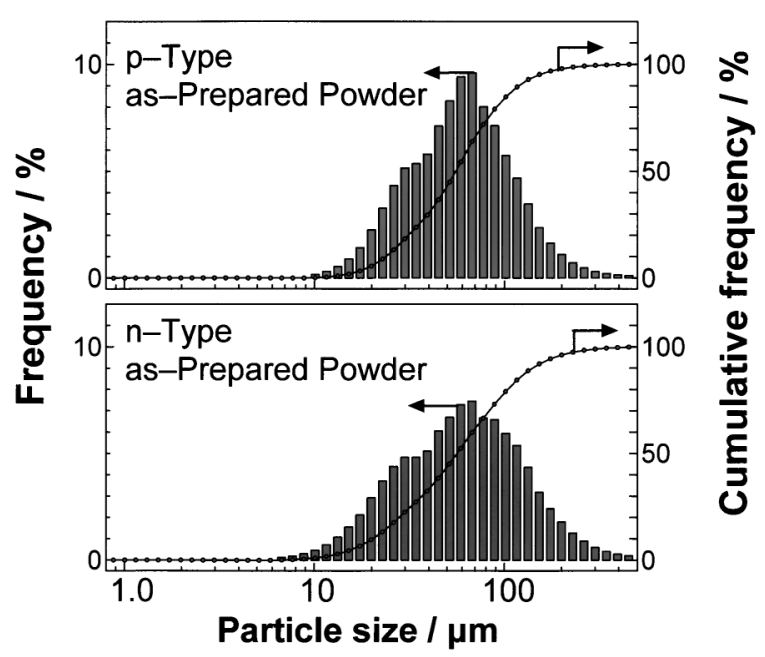

Fig. 2. Particle size distributions of as-prepared p- and n-type powders.
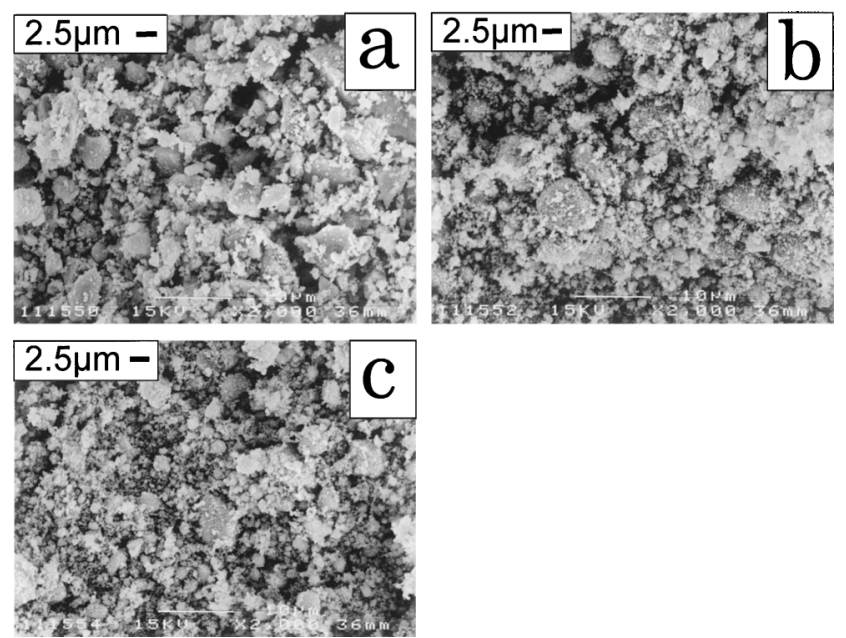

Fig. 3. SEM images of pulverized n-type $\mathrm{Si}-\mathrm{Ge}$ powders ballmilled for (a) $1 \mathrm{~h}$, (b) $10 \mathrm{~h}$ and (c) $50 \mathrm{~h}$.

powder by prolonged ball-milling time. Consequently, the mean particle size of the powder decreased until $10 \mathrm{~h}$, while it increased thereafter, as shown in Table 2. Therefore, the densification was hereafter carried out using the $\mathrm{p}$ - and n-type powders ball-milled for $10 \mathrm{~h}$, of which the mean particle sizes were 3.0 and $2.6 \mu \mathrm{m}$, respectively. 


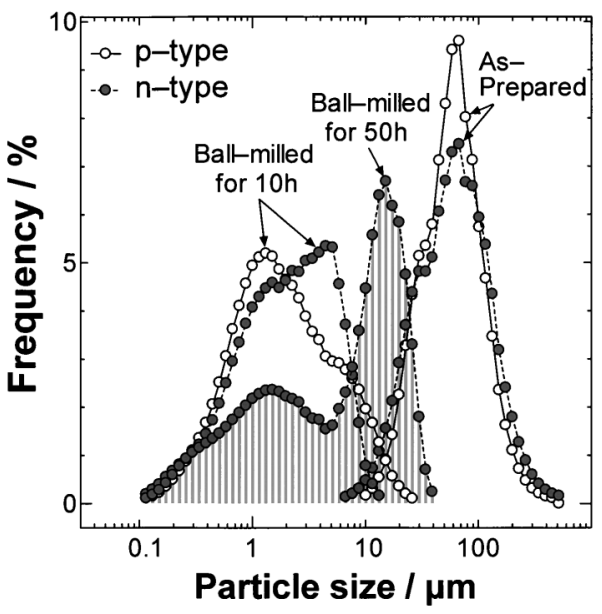

Fig. 4. Change in particle size distribution of as-prepared $\mathrm{Si}-\mathrm{Ge}$ powders by ball-milling.

Table 2. Mean Particle Size of Si-Ge as-Prepared and Their Pulverized Powders $(\mu \mathrm{m})$

\begin{tabular}{rcc}
\hline & p-type Si-Ge & n-type Si-Ge \\
\hline As-prepared & 72.1 & 66.1 \\
Pulverized 1h & - & 4.6 \\
$5 \mathrm{~h}$ & - & 3.2 \\
$10 \mathrm{~h}$ & 3.0 & 2.6 \\
$30 \mathrm{~h}$ & - & 9.2 \\
$50 \mathrm{~h}$ & - & 8.9 \\
\hline
\end{tabular}

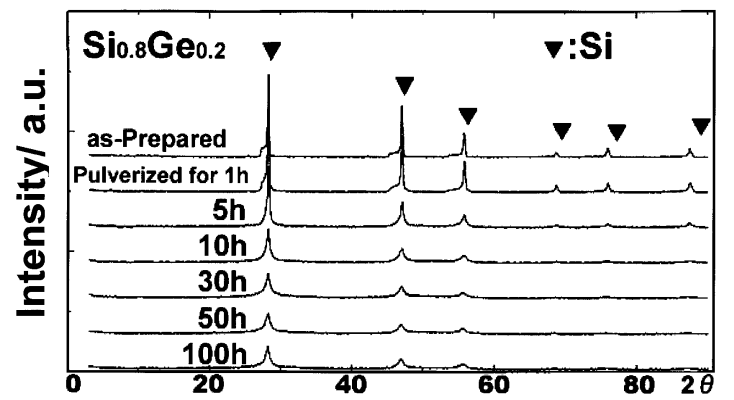

Fig. 5. XRD patterns of as-prepared n-type $\mathrm{Si}-\mathrm{Ge}$ powder and its pulverized powders ball-milled for 1-100 h.

Figure 5 shows the XRD patterns of pulverized n-type powders after ball-milling for $1-100 \mathrm{~h}$. It has been proven that all the XRD profiles originate from $\mathrm{Si}_{0.8} \mathrm{Ge}_{0.2}$ because they are located between those of $\mathrm{Si}$ and Ge. The XRD pattern indicated as-prepared powder to be in the fairy well-crystallized state. The intensities and widths of the peaks, respectively, decreased and increased gradually with the ball-milling time, which is probably due to the decrease in the crystallite size and the increase in the heterogeneous distortion in the particles, respectively. The XRD patterns of dense bodies that were made from these as-prepared and

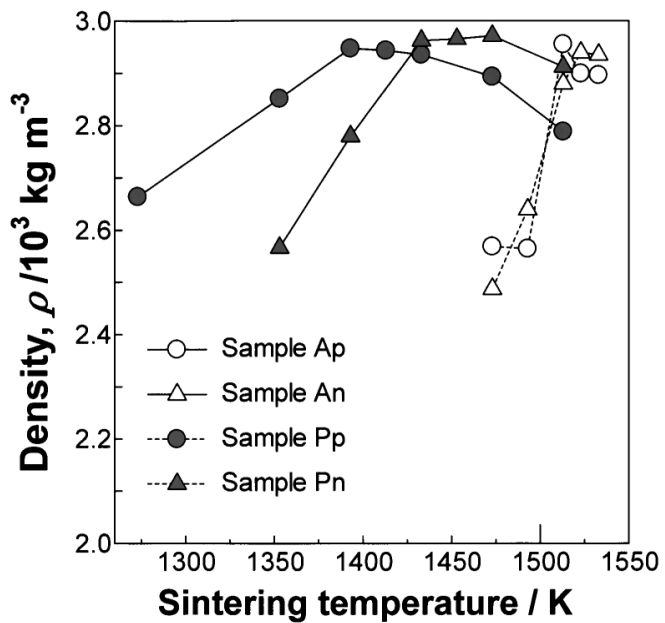

Fig. 6. Density of sintered bodies from as-prepared $\mathrm{p}$ - and n-type Si-Ge powders (samples $A_{p}$ and $A_{n}$, respectively) and their pulverized powders ball-milled for $10 \mathrm{~h}$ (samples $\mathrm{P}_{\mathrm{p}}$ and $\mathrm{P}_{\mathrm{n}}$, respectively).

pulverized powders by the pulse-current sintering indicated well-crystallized $\mathrm{Si}_{0.8} \mathrm{Ge}_{0.2}$.

\subsection{Densification}

The densities of samples $A_{p}$ and $A_{n}$ increased abruptly at approximately $1500 \mathrm{~K}$ to reach the final stage of densification, as shown in Fig. 6. The densities were $2.56-2.64 \times 10^{3} \mathrm{~kg} \cdot \mathrm{m}^{-3}$ at $1493 \mathrm{~K}$, and became more than $2.88 \times 10^{3} \mathrm{~kg} \cdot \mathrm{m}^{-3}$ above $1500 \mathrm{~K}$. That is, a temperature above $1500 \mathrm{~K}$ was required for the complete densification of as-prepared powders. The density of sample $\mathrm{P}_{\mathrm{p}}$ increased gradually until a temperature of $1393 \mathrm{~K}$ and then decreased, while that of sample $\mathrm{P}_{\mathrm{n}}$ increased rather abruptly until $1433 \mathrm{~K}$ and started to decrease at over $1473 \mathrm{~K}$.

In pulse-current sintering, the actual temperature of the sample was higher than the measured temperature in the carbon vessel. ${ }^{15)}$ The local melting of contact points between the particles occurred to facilitate neck growth by overheating due to local concentration of the electric current. 19),20) Consequently, the abrupt densification of as-prepared powders may be due to the liquefaction of small particles and the contact points between larger particles. The suitable sintering temperature range of these powders was limited within only $50 \mathrm{~K}$ because the melting point of $\mathrm{Si}_{0.8} \mathrm{Ge}_{0.2}$ was estimated to be $1550 \mathrm{~K}$ from the phase diagram of the $\mathrm{Si}-\mathrm{Ge}$ system. ${ }^{18)}$ It was proved that the precise control of the sintering temperature was required to obtain a dense body from the powders.

On the other hand, the slow densification of pulverized powders occurred at a lower temperature compared with as-prepared powders. The suitable sintering temperature for sufficient densification was in the range between 1400 and $1450 \mathrm{~K}$, which is much lower than the above estimated melting point of $1550 \mathrm{~K}$. The densification then seemed to proceed by solid-state sintering. The difference of the density between sample $\mathrm{P}_{\mathrm{p}}$ and $\mathrm{P}_{\mathrm{n}}$ increased with decreasing temperature, depending on the size distribution rather than the mean particle size. Table 2 shows almost the same particle size between two kinds of pulverized Si-Ge powders ball-milled for $10 \mathrm{~h}$, but Fig. 4 shows that the frequency less than $2 \mu \mathrm{m}$ of p-type pulverized powder surpasses that of n-type. The unexpected decreases in the densities of samples $\mathrm{P}_{\mathrm{p}}$ and $\mathrm{P}_{\mathrm{n}}$ above 1433 and $1473 \mathrm{~K}$, respectively, were presumably attributed to an expansion of the microcrack inside the body accompanied by the 
evaporation of $\mathrm{Ge}$ that was supported by compositional analysis using X-ray fluorescence spectrometry. The surface activation of pulverized powders due to the introduction of the distortion may promote the evaporation of Ge from samples $\mathrm{P}_{\mathrm{p}}$ and $\mathrm{P}_{\mathrm{n}}$. Sinterability of as-prepared p- and n-type Si-Ge powders was confirmedly improved with the mechanochemically increased surface energy of the powders by ball-milling.

Oxygen of 1.0-1.2 mass\% was contained in samples $\mathrm{P}_{\mathrm{p}}$ and $\mathrm{P}_{\mathrm{n}}$ as $\mathrm{SiO}_{2}$ and/or $\mathrm{GeO}_{2}$, which was 20 times more than those of samples $A_{p}$ and $A_{n}$. Pulse-current sintering was not interrupted by the surface oxide layers of the particles; the current passed through the shaped body without any interruption. 19),20) However, the above-mentioned effect of the reduction of the grain size surpassed that of the contamination on the sinterability of samples $P_{p}$ and $P_{n}$.

In comparison with the conventional hot pressing method, the densification and grain growth in this study were both similar ${ }^{7), 21)}$ but the working time of $180 \mathrm{~s}$ was remarkably short.

3.3 Microstructure and element distribution of sintered bodies

No microstructural difference was recognized between the $\mathrm{p}$ - and $\mathrm{n}$-type of samples $\mathrm{A}$ and $\mathrm{P}$ observed in the optical micrographs. The microstructures of samples $A_{p}, P_{p}$ and p-type $\mathrm{Si}$ from the corresponding gas-atomized powders are shown in micrographs in Figs. 7(a)-(c). For sample A, many irregularly shaped areas $10-40 \mu \mathrm{m}$ in length in light gray were observed in the matrix in dark gray (Fig. $7(\mathrm{a})$ ). Figure 7(b) shows sample $\mathrm{P}$ consisting of many fine particles less than $5 \mu \mathrm{m}$ in size. The grain boundaries were observed most clearly in the sample of pure $\mathrm{Si}$, as shown in Fig. 7 (c), the grain size of which was almost the same as that of sample A.

Figures $7(\mathrm{~d})$ and (e) are the mapping images of $\mathrm{Ge}$ of the samples $\mathrm{A}$ and $\mathrm{P}$, corresponding to Figs. 7(a) and (b), respectively. Figure 7 (d) revealed that the light gray areas in Fig. 7 (a) were rich in Ge. Further analysis of the Si and Ge distributions along the line from A to B in Fig. 7(a) was carried out, as shown in Fig. 8. The inhomogeneity of the Ge distribution of as-prepared $\mathrm{Si}-\mathrm{Ge}$ powder surface shown in Fig. 1 has been maintained in sample A, presumably due to a short time of $180 \mathrm{~s}$ for the pulse-current sintering. The area ratio of the Si-rich (dark gray) and Ge-rich (light gray) phases in Fig. 7(d) was determined to be 0.79 to 0.21 by conventional picture processing. Using the phase diagram of the $\mathrm{Si}-\mathrm{Ge}$ system, this ratio gave an apparent temperature of $1585 \mathrm{~K}$ for solidification, followed by the determination of the compositions of $85 \mathrm{Si} \cdot 15 \mathrm{Ge}$ (mass $\%$ ), and $61 \mathrm{Si} \cdot 39 \mathrm{Ge}$ of the dark and light gray areas, respectively. Finally, Fig. 7 (e) shows that the inhomogeneity of sample $\mathrm{P}$ was improved compared with that of sample A.

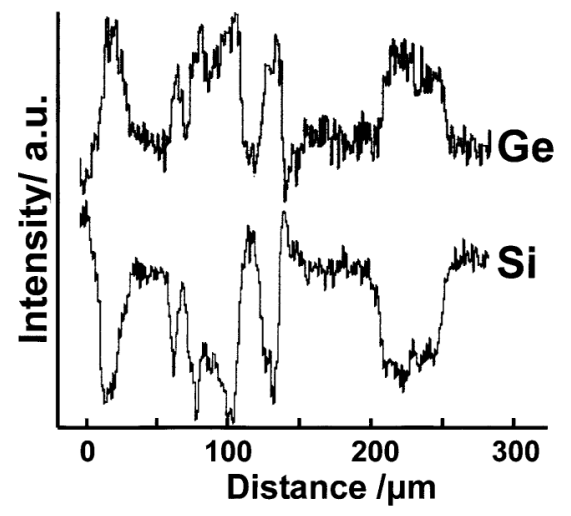

Fig. 8. Element distributions of $\mathrm{Si}$ and $\mathrm{Ge}$ along the line $\mathrm{A}-\mathrm{B}$ in Fig. 7 (a).
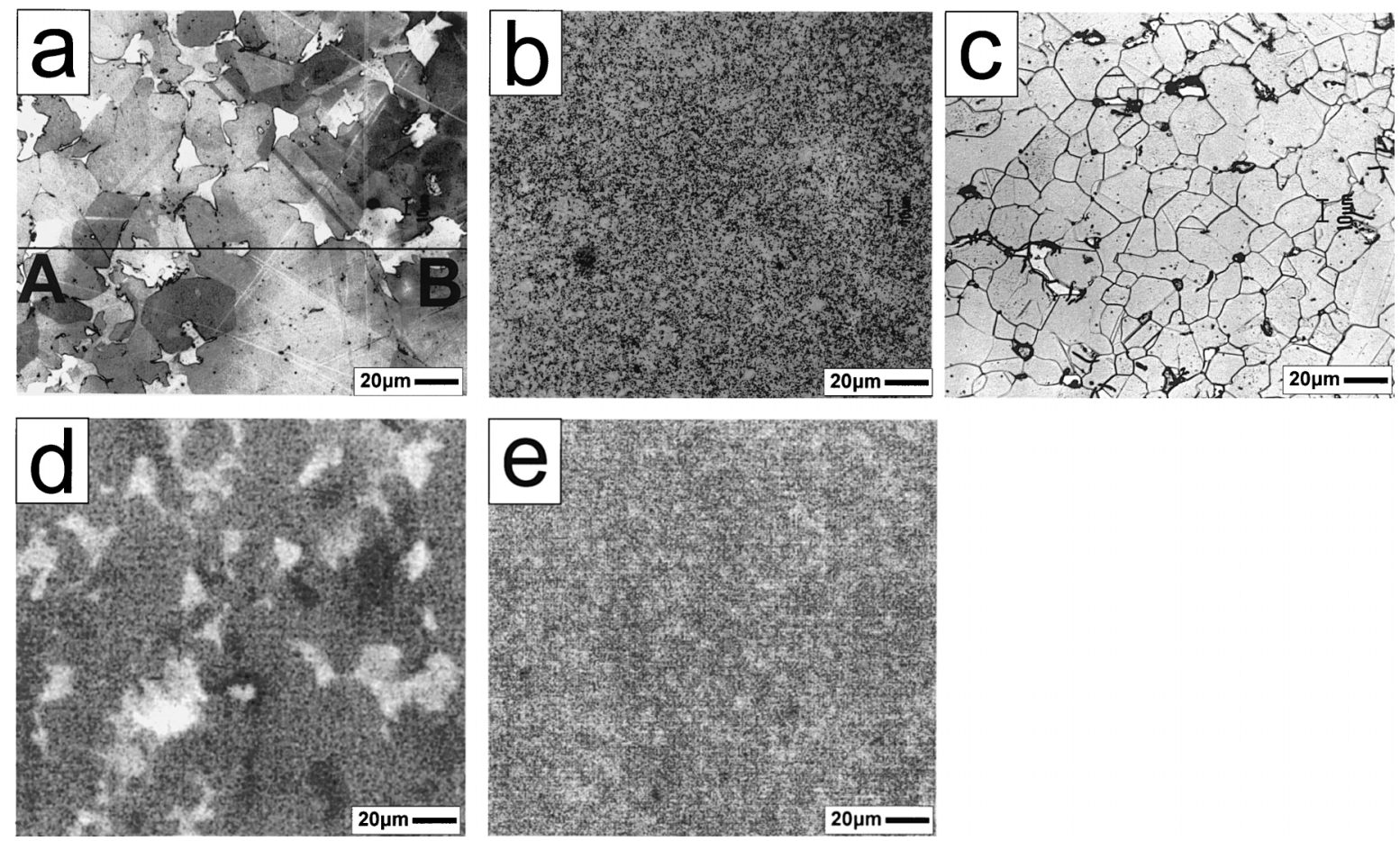

Fig. 7. Microstructures $(\mathrm{a}-\mathrm{c})$ and mapping image of $\mathrm{Ge}(\mathrm{d}, \mathrm{e})$ of sintered bodies. Microstructure of sintered bodies from (a) atomized p-type Si-Ge powder, (b) pulverized p-type Si-Ge powder and (c) atomized p-type Si powder (Si-0.5 mol\%P). The sintering temperatures of (a)-(c) are 1513, 1393 and $1513 \mathrm{~K}$, respectively. (d), (e): Mapping images of Ge from (a) and (b). Light gray: Ge-rich phase. 

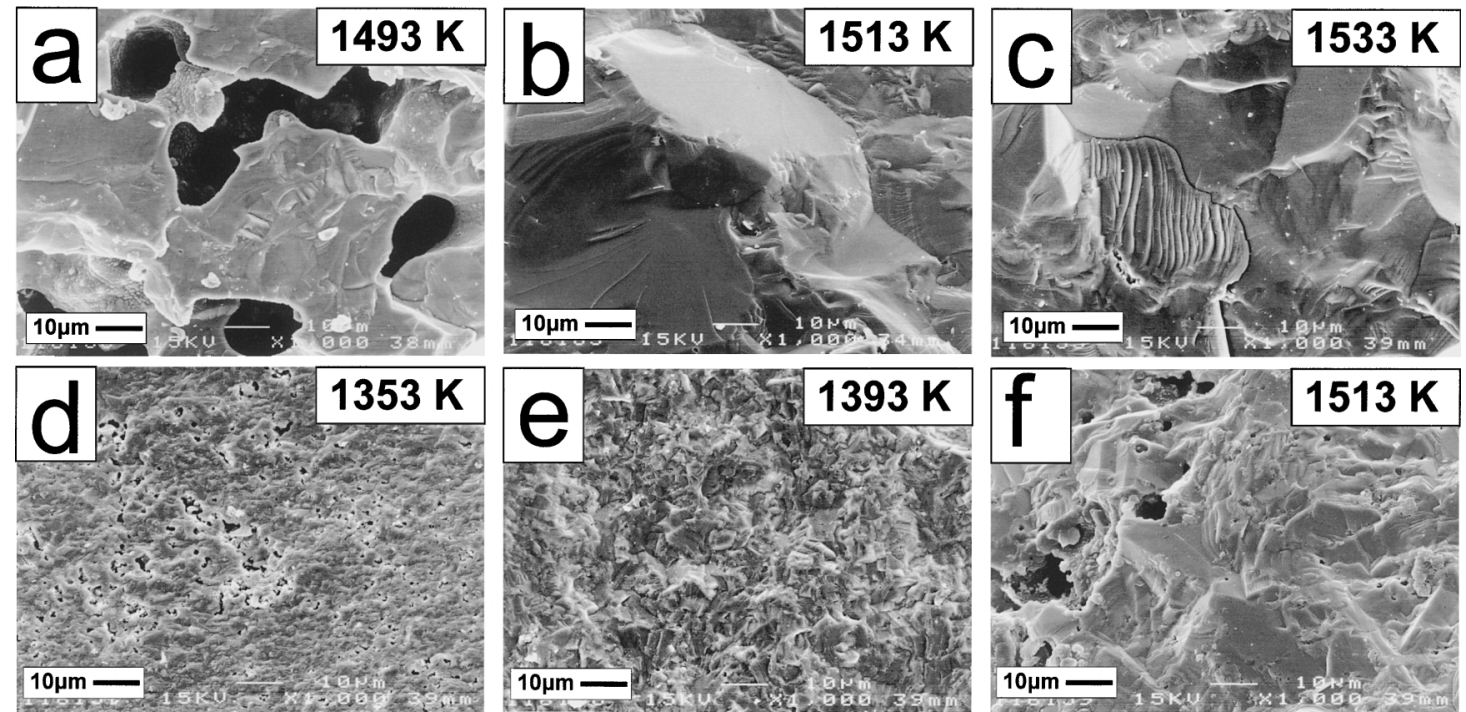

Fig. 9. Fracture surfaces of compact bodies from as-prepared p-type Si-Ge powder sintered at (a) $1493 \mathrm{~K}$, (b) $1513 \mathrm{~K}$ and (c) $1533 \mathrm{~K}$, and from its pulverized powder sintered at (d) $1353 \mathrm{~K}$, (e) $1393 \mathrm{~K}$ and (f) $1513 \mathrm{~K}$, respectively.

\subsection{Morphology of sintered bodies}

The SEM images of the fracture surfaces of samples $\mathrm{A}$ and $\mathrm{P}$ show the relationship between the sintering temperature and the microstructure of the dense bodies. Many micropores $10-50 \mu \mathrm{m}$ in length were observed in sample $A_{p}$ sintered at $1493 \mathrm{~K}$ (Fig. 9(a)), indicating the insufficient densification. The considerable densification of sample $A_{p}$ occurred in the narrow temperature range between 1493 and $1513 \mathrm{~K}$. The pores disappeared completely above $1513 \mathrm{~K}$ (Figs. 9(b) and (c)), having rough fracture surfaces. While fine pores less than $2 \mu \mathrm{m}$ in size were observed in sample $\mathrm{P}_{\mathrm{p}}$ sintered at $1353 \mathrm{~K}$ (Fig. 9 (d)), they disappeared at $1393 \mathrm{~K}$ (Fig. 9(e)). These fracture surfaces of sample $\mathrm{P}_{\mathrm{p}}$ sintered at 1353 and $1393 \mathrm{~K}$ consisted of small grains without growth. Figure 9 (f) shows the abrupt increase in the grain size and the regeneration of some pores in sample $\mathrm{P}_{\mathrm{p}}$ at $1513 \mathrm{~K}$. Particularly, the latter implies the formation of microcracks inside the body due to the evaporation of Ge. The enhancement of the sinterability of as-prepared powder pulverized by ball-milling was confirmed from the comparison between the fracture surfaces of samples $A_{p}$ and $P_{p}$ sintered at $1513 \mathrm{~K}$ and $1393 \mathrm{~K}$ (Figs. 9 (b) and (e)), respectively. This finding was also supported by the difference in the transverse rupture strengths of samples $A_{p}$ and $P_{p}$ (Figs. 9(b) and (e)) of the same density of almost $100 \%$, which were $118 \mathrm{MPa}$ and $161 \mathrm{MPa}$, respectively.

\section{Conclusions}

Both p- and n-type $\mathrm{Si}_{0.8} \mathrm{Ge}_{0.2}$ powders $(\mathrm{Si}: \mathrm{Ge}: \mathrm{B}=79.7$ : $20.1: 0.21 \mathrm{~mol} \%$ for p-type and $79.8: 20.0: 0.18 \mathrm{~mol} \%$ for n-type) oriented to the thermoelectric element were prepared by gas atomization of the corresponding melts, followed by densification using a pulse-current sintering technique. These Si-Ge powders were characterized and their sinterability was then studied. The effect of ballmilling on the sinterability of the powders was also discussed. The composition of as-prepared n-type Si-Ge powder was different from the batch compositions due to melting and evaporation of the dopant at a high temperature. The mean particle sizes of as-prepared p- and n-type Si-Ge powders were 72 and $66 \mu \mathrm{m}$, respectively. The mean particle sizes of both types of as-prepared powders were shifted to 3.0 and $2.6 \mu \mathrm{m}$ by ball-milling for $10 \mathrm{~h}$, respectively. The decrease in the crystallite size and the increase in the heterogeneous distortion in the particles correlated with the ball-milling time. The densification of as-prepared powders was abruptly promoted above $1500 \mathrm{~K}$; however, the densification temperature of the ball-milled powders decreased by approximately $100 \mathrm{~K}$. That is, the sinterability of as-prepared powders was improved with the decrease in the crystallite size and the increased surface distortion mechanochemically introduced by ball-milling. The grain size and elemental inhomogeneity of the dense bodies were both reduced.

Acknowledgment The authors wish to express their appreciation to Mr. Takayoshi Shimizu and Dr. Koichi Morii of Daido Steel Company for their assistance in the preparation of gasatomized powders.

\section{References}

1) Wood, C., Rep. Prog. Phys., Vol. 51, pp. 459-539 (1988).

2) Rowe, D. M., J. Power Sources, Vol. 19, pp. 247-259 (1987).

3) Vining, C. and Fleurial, J. P., "Silicon Germanium- An overview of Recent Developments," Ed. by Rowe, D. M., Babrow Press, Cardiff, United Kingdom (1991) pp. 1-14.

4) Scoville, N., Bajgar, C., Rolfe, J., Fleurial, J. P. and Vandersande, J., Proc. 28th Intersociety Energy Conversion Engineering Conference (1993) pp. 1227-1233.

5) Fleurial, J. P., Borshchevsky, A. and Vandersande, J. W., AIP Conference Proceedings (1991) pp. 451-457.

6) Scoville, N., Bajgar, C., Vandersande, J. and Fleurial, J. P., Proc. 27th Intersociety Energy Conversion Engineering Conference (1992) pp. 3465-3470.

7) Vining, C. B., Laskow, W., Hanson, J. O., Beck, R. R. and Gorsuch, P. D., J. Appl. Phys., Vol. 69, pp. 4333-4340 (1991).

8) Beaty, J. S., Rolfe, J. L. and Vandersande, J., American Institute of Physics AIP Conference Proceedings (1991) pp. 446-450.

9) Beaty, J. S., Rolfe, J. L., Vandersande, J. and Fleurial, J. P., Proc. 27th Intersociety Energy Conversion Engineering Conference (1992) pp. 3471-3475.

10) Lowley, A., J. Metals, Vol. 33, pp. 1-13 (1981).

11) Lubanska, H., J. Metals, Vol. 22, pp. 45-49 (1970).

12) Helmersson, G., Hede, A., Johannesson, T., Bergman, B., Hallen, H. and Burgdorf, K., "Advances in Powder 
Metallurgy \& Particulate Materials-1996,” Ed. by Cadle, T. and Narasimhan, K. S., Metal Powder Industries Federation, Princeton, New Jersey, USA (1996) pp. 1-109-1-124.

13) Miller, S. A., Feingold, E. and Vining, C. B., Modern Developments in Powder Metallurgy, Vol. 17, pp. 671-682 (1985).

14) Omori, M., Mater. Sci. Eng., Vol. A287, pp. 183-188 (2000).

15) Kim, H. T., Kawahara, M. and Tokita, M., Powder and Powder Metall., Vol. 47, pp. 887-891 (2000).

16) Wang, S. W., Chen, L. D. and Hirai, T., J. Mater. Res., Vol. 15, pp. 982-987 (2000).
17) Noguchi, T., Proc. 16th Int. Conf. on Thermoelectrics (1997) pp. 207-214.

18) Nihon Kinzoku Gakkai ed., "Kinzoku Data Book," 3rd ed. (1993) pp. 545-545.

19) Nagae, T., Yokota, M., Nose, M., Tomida, S., Kamiya, T. and Saji, S., Mater. Trans., Vol. 43, pp. 1390-1397 (2002).

20) Murayama, N., Ceramics Japan, Vol. 32, pp. 445-449 (1997) [in Japanese].

21) Rowe, D. M. and Shukla, V. S., J. Appl. Phys., Vol. 52, pp. 7421-7426 (1981). 